\title{
Effects of rose bengal on bile secretion in the rabbit: inhibition of a bile salt-independent fraction
}

\author{
D. DHUMEAUX ${ }^{1}$, S. ERLINGER, J.-P. BENHAMOU, AND R. FAUVERT
} with the technical assistance of Micheline Dumont and Marie-Therèse Forestier

From L'Unité de Recherches de Physiopathologie hépatique, Hôpital Beaujon, 92-Clichy, France

SUMMARY The authors have studied the influence of rose bengal, and, by comparison, of uranin, on choleresis in the rabbit. Uranin induced an increase in bile flow and a decrease in $\vec{\ominus}$ bile salt concentration in bile. These results are consistent with an osmotic mechanism, as ${ }^{\circ}$ proposed by Sperber (1959). By contrast, rose bengal induced a marked decrease in bile flow and an increase in bile salt concentration. In rose bengal-treated animals $\left(30 \mu\right.$ moles per $\frac{\partial}{0}$ kilogram body weight intravenously), bile flow was $65 \%$ lower and bile salt concentration

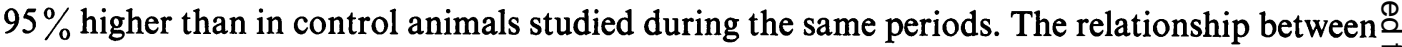
bile flow and bile salt excretion is consistent in the rabbit, with the existence of a bile salt- $\overrightarrow{\vec{O}}$ independent secretion of $60 \mathrm{mg}$ per minute per kilogram body weight, that is, $60 \%$ of bile flow. In rose bengal-treated animals, this fraction was only $15 \mathrm{mg}$ per minute per kilogramo body weight. It is concluded that rose bengal inhibits the bile salt-independent fraction.

Rose bengal, as other phtalein dyes, is excreted by the liver cells. Its effect on the bile saltindependent fraction suggests that this fraction is secreted by the hepatocytes.

In the course of studies on dye elimination by the liver in the rabbit, marked differences have been observed between the effects of various phtalein dyes on bile flow. Uranin, as previously noted by others, Sperber (1959), was choleretic. By contrast, rose bengal induced a marked decrease in bile flow, and studies were therefore ${ }^{1}$ To whom requests for reprints should be addressed. designed to examine the mechanism of this effect.

Present concepts on organic anion transport 8 by the liver cell suggested that the decrease of choleresis observed after rose bengal adminis-

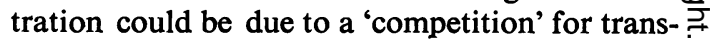
port between rose bengal and bile salts (Fauvert, Benhamou, and Loverdo, 1958). The results indicate that such a 'competition' alone cannot 
account for the reduction in bile flow, which appears to be due mainly to inhibition of a bile salt-independent fraction recently demonstrated in the rabbit (Erlinger, Dhumeaux, Benhamou, and Fauvert, 1969).

\section{Material and Methods}

All the experiments were performed on rabbits weighing $2 \cdot 5$ to 3.5 kilograms.

\section{EXPERIMENTAL PROCEDURES}

After intravenous mebubarbital anaesthesia, the trachea was connected to a respirator. Body temperature was maintained between 37.5 and $38.5^{\circ} \mathrm{C}$. Arterial pressure was measured throughout the experiment. After cystic duct ligation, the common bile duct was cannulated with a polyethylene catheter. Bile was collected in weighed tubes during successive 10 -minute periods. Fluid and electrolyte losses were replaced continuously by $0 \cdot 15 \mathrm{M} \mathrm{NaCl}$ infusion.

In five animals, after a control period of 40 minutes, a single dose of $30 \mu$ moles per kilogram body weight of rose bengal (mol wt 1,018 ) was given intravenously. Bile was collected during the following 50 minutes. Bile flow and glycodeoxycholic acid concentration in bile were measured in each 10-minute sample. The same parameters were studied in five control animals receiving no rose bengal.

Five animals received uranin (disodium fluorescein, mol wt 376) instead of rose bengal; the experimental procedure was modified as follows: because of significant urinary elimination of the dye, ureters were ligated in order to achieve higher biliary concentrations, and because of the transient effect of uranin on choleresis after a single injection, an initial 'priming' dose of 80 $\mu$ moles per kilogram body weight was followed by a continuous infusion at a rate of $8 \mu$ moles per minute per kilogram body weight. Bile was again collected during 50 minutes. Bile flow and glycodeoxycholic acid concentration were measured. Five control animals with ligated ureters received no uranin and were studied under the same conditions.

\section{ANALYTICAL PROCEDURES}

Glycodeoxycholic acid concentration in bile was determined by spectrophotometry after thinlayer chromatography; details are given elsewhere (Erlinger et al, 1969). The presence of rose bengal or uranin in bile did not influence the results: the chromatographic $R f$ of rose bengal and uranin were different from that of glycodeoxycholic acid; the addition of either dye to the eluate did not modify the optical densities obtained with the bile acid alone.

\begin{tabular}{llll}
\hline Bile Flow & $\begin{array}{l}\text { Before Rose } \\
\text { Bengal }\end{array}$ & $\begin{array}{l}\text { After Rose } \\
\text { Bengal }\end{array}$ & $\begin{array}{l}\text { Percentage } \\
\text { Decrease }\end{array}$ \\
\cline { 2 - 4 }$($ mg/min/kg body weight $)$ & \\
\hline & $100 \cdot 5$ & 27.9 & 72.2 \\
& $100 \cdot 3$ & 30.2 & 70.0 \\
& 113.1 & 28.2 & 75.1 \\
& 87.5 & 36.8 & 58.0 \\
& 96.6 & 25.5 & 73.6 \\
Mean & 99.6 & 29.7 & 69.8 \\
Standard & 9.2 & 4.3 & 6.8 \\
deviation & 9.2 &
\end{tabular}

Table I Effect of rose bengal (30 $\mu$ moles/ $\mathrm{kg}$ body weight intravenously) on rabbit bile flow

${ }^{1}$ Bile flow was measured during the first $\mathbf{4 0}$ minutes of the experiments and again from 10 to 50 minutes after rose bengal injection.

\begin{tabular}{llll}
\hline $\begin{array}{l}\text { Glycodeoxy- } \\
\text { cholic Acid } \\
\text { Concentration }\end{array}$ & $\begin{array}{l}\text { Before } \\
\text { Rose } \\
\text { Bengal }\end{array}$ & $\begin{array}{l}\text { After } \\
\text { Rose } \\
\text { Bengal }\end{array}$ & $\begin{array}{l}\text { Percentage } \\
\text { Increase }\end{array}$ \\
\cline { 2 - 4 } & (umoles/ml) & & \\
\hline & 5.1 & 12.5 & 145.1 \\
& $9 \cdot 8$ & 9.6 & -02.0 \\
& 6.5 & 10.5 & 61.5 \\
& 7.8 & 8.3 & 06.4 \\
Mean & 6.3 & 10.7 & 69.8 \\
Standard & 7.1 & 10,3 & 56.2 \\
deviation & 1.8 & 1.5 & 59.1 \\
\hline
\end{tabular}

Table II Effect of rose bengal (30 $\mu$ moles $/ \mathrm{kg}$ body weight intravenously) on glycodeoxycholic acid concentration in rabbit bile

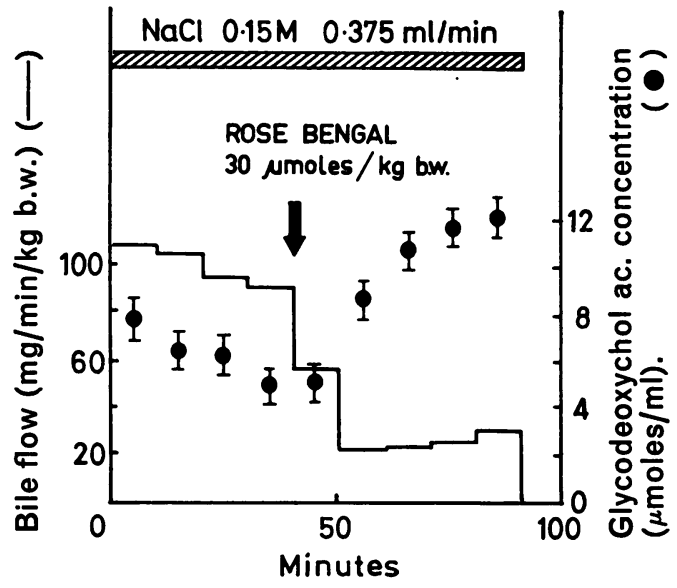

Fig. 1 Influence of rose bengal on bile flow and bile acid concentration in the rabbit. An infusion of $0.15 \mathrm{M} \mathrm{NaCl}$ is given throughout the experiment to replace water and electrolyte losses. Bile salt concentration is represented by the mean of two duplicate determinations. The vertical bar indicates the standard error of the method, obtained from 51 duplicate determinations. 

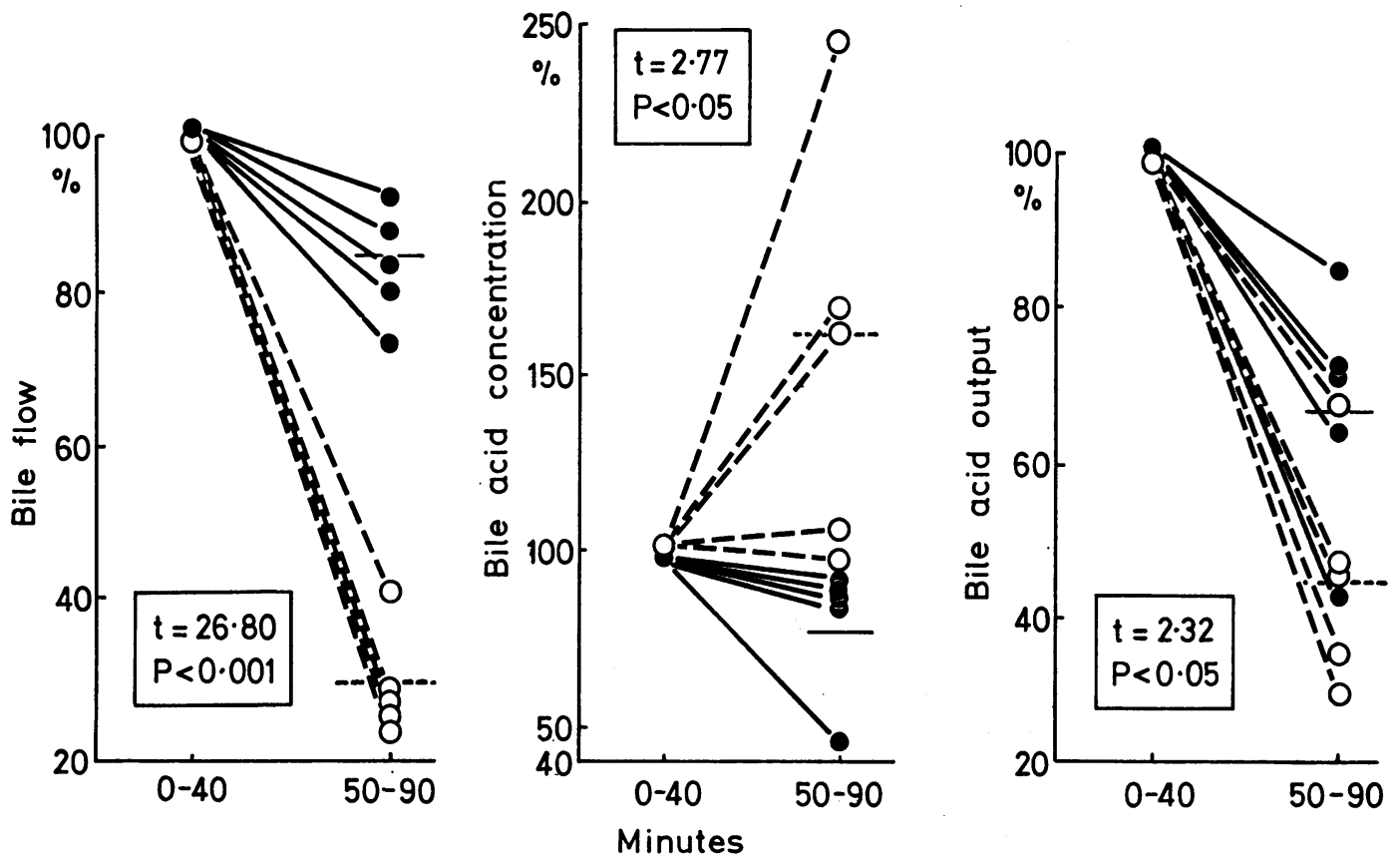

Fig. 2 The effect of rose bengal on bile flow (on the left), bile salt concentration (in the middle), and excretion (on the right) in rabbit bile. The animals receiving rose bengal are represented by the open circles $(\mathrm{O})$ and the control animals by the black circles (O).

The initial bile flow was measured during the first 40 minutes $(0-40)$ and is represented as $100 \%$. The rose bengal was injected at 40 minutes $(30 \mu$ moles per kg body weight). The period after rose bengal injection was 50 to 90 minutes (50-90).

In rabbit bile, glycodeoxycholic acid represents approximately $80 \%$ of total bile acids (Erlinger et al, 1969; Gregg and Poley, 1966). In four experiments, the concentration of glycodeoxycholic acid and of the other bile acids varied in parallel. In all other experiments, only glycodeoxycholic acid was measured, and its concentration was assumed to be a satisfactory estimate of total bile acid concentration. The implications of this approximation on the interpretation of the results will be mentioned.

\section{Results}

ROSE BENGAL STUDIES

Effect on bile flow

Rose bengal induced a prompt and marked decrease in bile flow. A typical experiment is $N$ represented in Figure 1. In the five animals, when N the mean bile flow from the 10th to the 50th minute after rose bengal injection was compared with bile flow during the 40-minute control period, a decrease of $69 \cdot 8 \pm$ SD $6.8 \%$ was observed. The corresponding decrease in the five animals 0 receiving no rose bengal was only $15.8 \pm$ SD $7 \cdot 0 \%$ (Table I, Figure 2). The difference between $\Phi$ the two groups is highly significant $\left(t=23 \cdot 80\right.$, $\frac{\mathbb{D}}{\circ}$ $P<0.001)$. If the spontaneous decrease of bile 0 flow is considered, the actual decrease due to rose bengal is only $63 \%$.

A decrease in bile flow was observed with a dose of $5 \mu$ moles per kilogram body weight; the $\frac{\bar{\theta}}{7}$ maximal decrease in bile flow seemed to be ob- ? served for a dose of $30 \mu$ moles per kilogram body weight (Figure 3).

The decrease in bile flow was prolonged: bile 


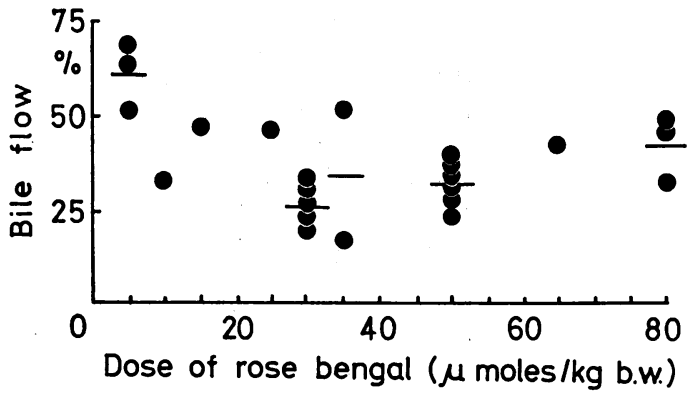

Fig. 3 Relationship between the administered dose of rose bengal and the decrease in bile flow. Bile flow is indicated as a percentage of initial bile flow. It can be noted that the spontaneous decrease in bile flow, observed in control animals during the same period, is approximately $10 \%$.

flow did not return to normal during periods up to two hours after injection.

\section{Effect on bile acid excretion}

After rose bengal administration, biliary concentration of glycodeoxycholic acid increased. The mean glycodeoxycholic acid concentration was $7 \cdot 1 \pm$ SD $1.8 \mu$ moles $/ \mathrm{ml}$ during the control period and 10.3 \pm SD 1.5 after rose bengal injection. This represented a mean increase of $56.2 \pm$ SD $59 \cdot 1 \%$, whereas a decrease of $20.6 \pm$ SD $18.3 \%$ was observed during the same period in the control animals (Table II, Figure 2). The difference between the two groups is significant $(t=2.77, P<0.05)$. If the spontaneous decrease in bile salt concentration is considered, the increase due to rose bengal is $95 \%$.

As a result of the marked decrease in bile flow, and in spite of the increase in glycodeoxycholic acid concentration, bile acid excretion was lower after rose bengal administration than in the control animals. The mean spontaneous decrease was $33.8 \pm$ SD $15.8 \%$, whereas the decrease after rose bengal was $55.9 \pm 14.7 \%$ (Table III, Figure 2). The difference is significant $(t=2.32, P<0.05)$. If the spontaneous decrease in bile salt excretion is considered, the decrease due to rose bengal is $33 \%$.

\section{Bile flow-bile acid excretion relationship}

The bile flow-bile acid excretion rate relationship was studied in the four samples collected from 10 to 50 minutes after rose bengal injection. It was observed that bile flow was linearly related to bile salt excretion rate; the slope, ie, the increment of bile flow per $\mu$ mole of bile salt excreted, was $48.9 \mathrm{mg} / \mu$ mole; extrapolation to a zero bile salt excretion indicated a flow of $\mathbf{1 5 . 2}$ mg per minute per kilogram body weight (confidence interval: $3 \cdot 2-27 \cdot 1$ ) (Figure 4).

\begin{tabular}{|c|c|c|c|}
\hline \multirow[t]{3}{*}{$\begin{array}{l}\text { Glycodeoxy- } \\
\text { cholic Acid } \\
\text { Excretion }\end{array}$} & $\begin{array}{l}\text { Before } \\
\text { Rose } \\
\text { Bengal }\end{array}$ & $\begin{array}{l}\text { After } \\
\text { Rose } \\
\text { Bengal }\end{array}$ & \multirow[t]{2}{*}{$\begin{array}{l}\text { Percentage } \\
\text { Decrease }\end{array}$} \\
\hline & \multicolumn{2}{|c|}{$(\mu \mathrm{moles} / \mathrm{min} / \mathrm{kg}$ body weight $)$} & \\
\hline & $\begin{array}{l}0.52 \\
0.99 \\
0.85 \\
0.68 \\
0.61\end{array}$ & $\begin{array}{l}0.35 \\
0.29 \\
0.29 \\
0.31 \\
0.27\end{array}$ & $\begin{array}{l}32.7 \\
70.7 \\
65.9 \\
54.4 \\
55.8\end{array}$ \\
\hline $\begin{array}{l}\text { Mean } \\
\text { Standard } \\
\text { deviation }\end{array}$ & 0.73 & $0 \cdot 30$ & 55.9 \\
\hline
\end{tabular}

Table III Effect of rose bengal (30 $\mu$ moles $/ \mathrm{kg}$ body weight intravenously) on glycodeoxycholic acid excretion in rabbit bile

\begin{tabular}{llrl}
\hline Bile Flow & $\begin{array}{l}\text { Before } \\
\text { Uranin } \\
\text { Infusion }\end{array}$ & $\begin{array}{l}\text { During } \\
\text { Uranin } \\
\text { Infusion }\end{array}$ & $\begin{array}{l}\text { Percentage } \\
\text { Increase }\end{array}$ \\
\cline { 2 - 3 } & \multicolumn{2}{l}{ (mg/min/kg body weight $)$} & \\
\hline & $61 \cdot 1$ & 92.9 & 52.0 \\
& 76.2 & 107.4 & 40.9 \\
& 70.9 & 93.4 & 31.7 \\
& 40.4 & 70.4 & 74.0 \\
Mean & 55.0 & 104.3 & 89.6 \\
$\begin{array}{llll}\text { Standard } \\
\text { deviation }\end{array}$ & 60.7 & 93.7 & 57.6 \\
\hline
\end{tabular}

Table IV Effect of uranin $(8 \mu$ moles $/ \mathrm{min} / \mathrm{kg}$ body weight intravenously) on rabbit bile flow

${ }^{1}$ Bile flow was measured during the first $\mathbf{4 0}$ minutes of the experiments and again from 10 to 50 minutes after the uranin infusion was started.

\begin{tabular}{llll}
\hline $\begin{array}{l}\text { Glycodeoxy- } \\
\text { cholic Acid } \\
\text { Concentration }\end{array}$ & $\begin{array}{l}\text { Before } \\
\text { Uranin } \\
\text { Infusion }\end{array}$ & $\begin{array}{l}\text { During } \\
\text { Uranin } \\
\text { Infusion }\end{array}$ & $\begin{array}{l}\text { Percentage } \\
\text { Decrease }\end{array}$ \\
\cline { 2 - 4 } & (umoles/ml) & & \\
\hline & 10.3 & 4.0 & 61.2 \\
& 9.6 & 3.1 & 67.7 \\
& 12.1 & 4.9 & 59.5 \\
& 11.2 & 3.4 & 69.6 \\
& 10.5 & 3.4 & 67.6 \\
Mean & 10.7 & 3.8 & 65.1 \\
Standard & 1.0 & 0.7 & 4.5 \\
deviation & 1.0 & 0.7 & 4.5 \\
\hline
\end{tabular}

Table $\mathrm{V}$ Effect of uranin $(8$ umoles $/ \mathrm{min} / \mathrm{kg}$ body weight intravenously) on glycodeoxycholic acid concentration in rabbit bile

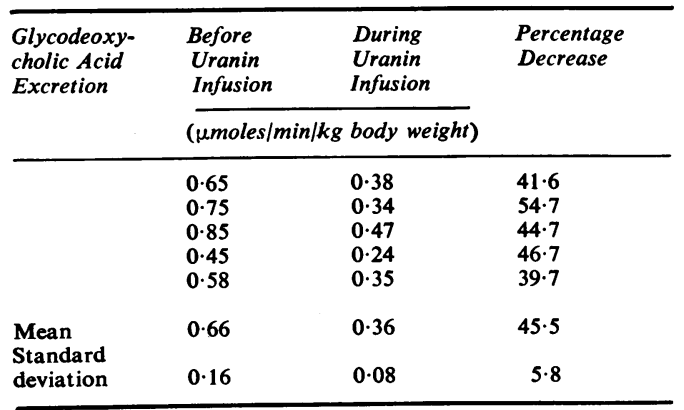

Table VI Effect of uranin $(8 \mu$ moles $/ \mathrm{min} / \mathrm{kg}$ body weight intravenously) on glycodeoxycholic acid excretion in rabbit bile 


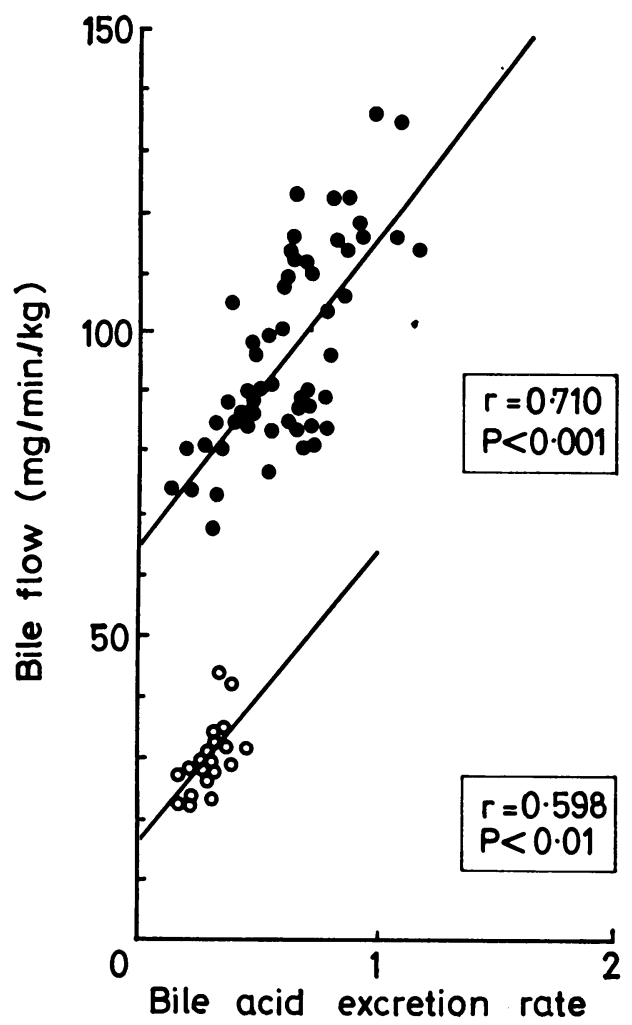

(Glycodeoxycholic ac. $\mu$ moles $/ \mathrm{min} / \mathrm{kg}$ )
Fig. 4 Relationship between bile flow and bile salt excretion in the rabbit. Nine animals receiving $0.15 \mathrm{M} \mathrm{NaCl}$ infusion are represented by the black circles (O); the equation of the line is $y=52 \cdot 8 x+64 \cdot 1$; extrapolation to a zero bile salt excretion indicates a bile salt-independent output of $64 \cdot 1 \mathrm{mg}$ per minute per $\mathrm{kg}$ body weight (confidence interval; 52.1-76.1) (Erlinger et al, 1969). The animals receiving rose bengal are represented by the open circles $(O)$; the equation of the line is $y=48.9 x+15 \cdot 2$; extrapolation to a zero bile salt excretion indicates $a$ bile salt-independent output of $15.2 \mathrm{mg}$ per minute per $k g$ body weight (confidence interval $3 \cdot 2-27 \cdot 1$ ).
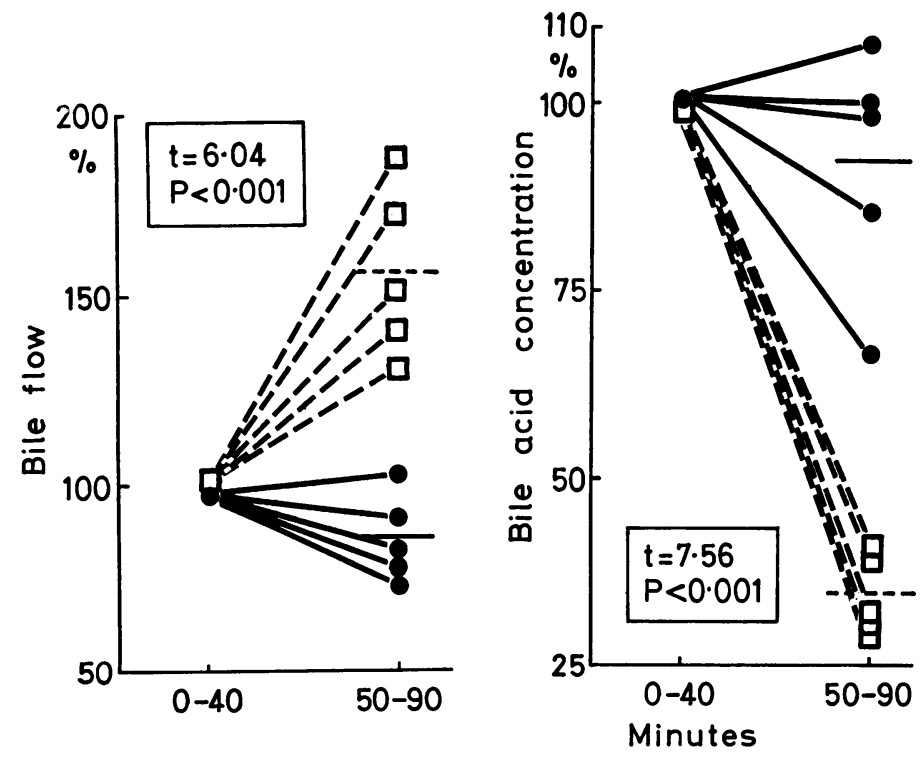

Fig. 5 Bile flow, bile salt concentration and excretion in animals receiving uranin infusion (open squares: $\square)$, compared with control animals (black circles: 0 ). The initial bile flow was measured during the first 40 minutes $(0-40)$ and is represented as $100 \%$.

Uranin infusion was started at 40 minutes, at a rate of $8 \mu$ moles per minute per $\mathrm{kg}$ body weight, and the uranin test period was 50 to 90 minutes (50-90).

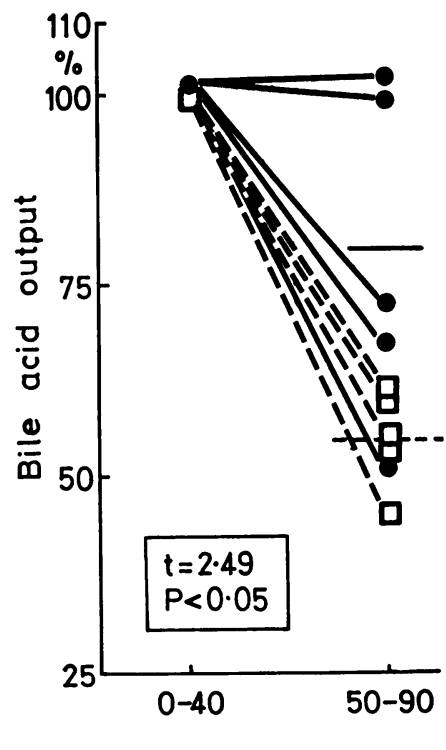

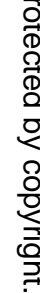




\section{URANIN STUDIES}

\section{Effect on bile flow}

Venous infusion of $8 \mu$ moles per minute per kilogram body weight of uranin induced a significant increase in bile flow. In the five animals, the mean increase was $57.6 \pm$ SD $23.8 \%$ compared with a mean decrease of $14.4 \pm$ SD $12.0 \%$ in the control animals during the same period (Table IV, Figure 5). The difference is highly significant $(t=6.04, P<0.001)$.

\section{Effect on bile acid excretion}

Uranin induced a significant decrease in glycodeoxycholic acid concentration: during uranin infusion, concentration decreased by $65 \cdot 1 \pm$ SD $4.5 \%$, whereas in the control animals, it decreased by $7 \cdot 7 \pm$ SD $16 \cdot 3 \%$ (Table V, Figure 5 ). The difference is highly significant $(t=7 \cdot 56, P<$ 0.001 ). The bile acid excretion rate was lower in the animals receiving uranin (mean decrease $45.5 \pm$ SD $5.8 \%$ ) than in the controls (mean decrease $20.9 \pm$ SD $21.7 \%$ ) (Table VI, Figure 5). The difference is again significant $(t=2.49$, $P<0.05)$.

\section{Comments}

It is generally admitted that the energy necessary to initiate bile formation is provided by active secretion of bile salts by the hepatocytes into the canaliculi (Sperber, 1956). According to Sperber (1959), the mechanism through which bile salts promote choleresis is osmotic in nature. This concept is supported by the observation that other osmotically active compounds may also have a choleretic effect: uranin in the rat (Sperber, 1959) and bromsulphalein in the dog (Hoenig and Preisig, 1969) possess such a property. The results observed with uranin are consistent with this hypothesis and confirm the choleretic effect of this phtalein dye in the rabbit. The osmotic gradient created by the high concentration of uranin in the canaliculi provides the driving force for water. As a result, bile flow increases and bile salt concentration decreases.

Although highly concentrated in bile, rose bengal, by contrast, induced a marked and prompt decrease in bile flow and an increase in bile salt concentration. Two tentative explanations can be proposed. The first could be a decrease of the osmotic activity of bile salts in the presence of rose bengal. This hypothesis is very unlikely for the following reason: as already established (Erlinger et al, 1969; Preisig, Cooper, and Wheeler, 1962), the slope of the linear relationship between bile flow and bile salt excretion rate indicates the amount of water excreted per mole of bile salt; the present data indicate that the slope is not significantly modified by rose bengal administration (Figure 4).

The alternative explanation for the effect of rose bengal on choleresis is a decrease in a bile salt-independent fraction. The results of earlier studies (Erlinger et al, 1969) are consistent with the secretion, in the rabbit, of a large bile salt-independent fraction, representing approximately $60 \%$ of spontaneous bile flow. The amount of the bile salt-independent fraction can be calculated indirectly by extrapolation of the relationship between bile flow and bile salt excretion rate to a zero bile salt excretion (Erlinger et al, 1969). It can be observed that the assimilation of glycodeoxycholic acid excretion to total bile acid excretion modifies the slope of the relationship between bile flow and bile salt excretion; however, it does not modify the calculation of the bile salt-independent fraction. The bile salt-independent fraction, which amounts to $60 \mathrm{mg}$ per minute per kilogram body weight in the controls, was only $15 \mathrm{mg}$ per minute per kilogram body weight after rose bengal administration (Figure 4). Rose bengal appears, therefore, to decrease markedly the bile salt-independent fraction. Moreover, the observation of a lower bile flow after rose bengal for a given bile salt excretion (Fig. 4) supports the existence of this bile salt-independent fraction.

A decrease in bile salt excretion was noted after the administration of both dyes, uranin as well as rose bengal. Such a decrease can be interpreted in terms of 'competition' phenomena. 'Competition' has been observed whenever two organic anions presumably excreted in bile through similar pathways are injected simultaneously: dehydrocholate decreases bromsulphalein elimination (Cantarow, Wirts, Snape, and Miller, 1948a); bromsulphalein decreases bilirubin excretion (Cantarow et al, 1948b). Similarly, the present results demonstrate that uranin and rose bengal decrease bile salt excretion. The decrease in bile salt excretion is approximately $30 \%$ and cannot explain the marked reduction in bile flow (approximately 65\%) observed after rose bengal administration.

Rose bengal, like other organic anions, is excreted by the hepatocytes. Its effect on the bile salt-independent fraction in the rabbit can be offered as indirect evidence of the hepatocytic origin of the bile salt-independent fraction in this animal. Such a hepatocytic bile saltindependent fraction has recently been postulated in the dog (Wheeler, Ross, and Bradley, 1968); however, in the latter animal, its output is considerably lower (Wheeler et al, 1968). Other dyes excreted by the liver through similar mechanisms seem to have the same effect as rose bengal; indocyanine green was found to induce a marked decrease of bile flow in the rabbit (Dhumeaux, unpublished data). 
We wish to thank Dr P. Berthelot for his help and criticism, and Mrs Suzanne Devoto and Miss Mireille Arnaud for their help in preparing the manuscript.

\section{References}

Cantarow, A., Wirts, C. W., Snape, W. J., and Miller, L. L. (1948a). Effect of certain choleretic agents on excretion of pigment and bromsulfalein in bile. Amer. J. Physiol. $154,506-512$.

Cantarow, A., Wirts, C. W., Snape, W. J., and Miller, L. L. (1948b). Excretion of bilirubin and bromsulfalein in bile. Amer. J. Physiol., 154, 211-219.

Erlinger, S., Dhumeaux, D., Benhamou, J.-P., and Fauvert, R. (1969). La sécrétion biliaire du lapin: preuves en faveur d'une importante fraction indépendante des sels biliaires. Rev. frans. Etud. clin. biol., 14, 144-150.
Fauvert, R., Benhamou, J.-P., and Loverdo, A. (1958). Considérations générales sur la notion de clearance hépatique. Rev. int. Hépat., 8, 429-450.

Gregg, J. A., and Poley, J. R. (1966). Excretion of bile acids in normal rabbits. Amer. J. Physiol., 211, 1147-1151.

Hoenig, V , and Preisig, R. (1969). Organic anionic choleresis in the dog: comparison of bile salts and bromsulfalein. In Proceedings of IVth Meeting of the European Association for the Study of the Liver. (Abstr.) Verlag der Wiener $\mathbb{D}$ medizinischen Akademie, Vienna.

Preisig, R., Cooper, H. L., and Wheeler, H. O. (1962). The rela- $\mathcal{O}$ tionship between taurocholate secretion rate and bile $\vec{P}$ production in the unanesthetized dog during cholinergic $\bigcirc$ blockade and during secret in administration, $J$, clin. Invest., 41, 1152-1162.

Sperber, I. (1959). Secretion of organic anions in the formation of urine and bile. Pharmacol. Rev. 11, 109-134.

Wheeler, H. O., Ross, E. D., and Bradley, S. E. (1968). Canalicular bile production in dogs. Amer. J. Physiol., 214, 866-874.

\section{The January 1970 Issue}

\section{THE JANUARY 1970 ISSUE CONTAINS THE FOLLOWING PAPERS}

Alterations in human intestinal microflora during experimental diarrhoea S. L. GORBACH, G. NEALE, R. LEVITAN, AND G. W. HEPNER

Response of the jejunal mucosa in adult coeliac disease to oral prednisolone ALFRED J. WALL, ADRIAN P. DOUGLAS, C. C. BOOTH, AND A. G. E. PEARSE

Peptide hydrolase activity of human intestinal mucosa in adult coeliac disease ADRIAN $P$. DOUGLAS AND T. J. PETERS

Cutaneous ulceration in Crohn's disease J. c. MOUNTAIN

Absorption and secretion of water and electrolytes by the intact human colon in diffuse untreated proctocolitis J. HARRIS AND R. SHIELDS

Measurement of gastrointestinal transmural electric potential difference in man MICHAEL G. GEALL, CHARLES F. CODE, DONALD C. MCILRATH, AND W. H. J. SUMMERSKILL

A case of ulcerative colitis and pyostomatitis vegetans in an African J. M. NAISH, B. D. BATCHVAROV, AND V. L. LAWOYIN

Physical factors in the stimulation of calonic peristalsis C. v. MANN

Response of the human oesophagus to d-tubocurarine and atropine P. A. KANTROWITZ, C. I. SIEGEL, M. J. STRONG, AND T. R. HENDRIX
Oesophageal hiatus hernia in three generations of one family I. J. CARRÉ AND P. FROGGATT

Role of occult blood loss in anaemia after partial gastrectomy I. MCLEAN BAIRD, D. J. B. ST. JOHN, AND SHAFIKA S. NASSER

Relationship between pancreatic secretion and pancreatic blood flow BERNARD GOODHEAD, HARRY S. HIMAL, AND JOSEPH ZANBILOWICZ

Effect of pressure on the integrity of the ductacinar system of the pancreas R. C. PIROLA AND A. E. DAVIS

Thoracic duct changes in schistosomal hepatic O fibrosis A. N. SADEK, A. ABOUL-ENEIN, E. HASSENEIN, AND A. ISMAIL

\section{Progress Report}

Caerulein V. ERSPAMER

\section{Technique}

New techniques for speeding small intestinal biopsy N. EVANS, L. J. FARROW, A. HARDING, AND J. S. STEWART

\section{Comment}

Notes and Activities

Notes on Books

Copies are still available and may be obtained from the PUBLISHING MANAGER, BRITISH MEDICAL ASSOCIATION, TAVISTOCK SQUARE W.C.1. price 17s. 6D. 